\title{
ANALISIS PENYELESAIAN SENGKETA EKONOMI SYARIAH PASCA PUTUSAN MK No. 93/PUU-X/2012
}

\author{
Oleh : Husni Kamal, MA
}

Email: husnikamal58@gmail.com

\begin{abstract}
Abstrak
Tujuan penelitian ini untuk mengetahui penyelesaian sengketa ekonomi syariah melalui jalur non-litigasi dan kekuatan hukum lembaga keuangan syariah yang masih menggunakan Pengadilan Negeri sebagai jalur litigasi. Adapun penelitian ini bersifat yuridis normatif yaitu melihat putusan MK No. 93/PUU-X/2012 dengan cara menganalisis putusan tersebut melalui pendekatan Undang-undang (statute approach). Kesimpulannya Sejak adanya putusan Mahkamah Konstitusi No. 93/PUU-X/2012 maka tidak ada lagi dualisme kewenangan pengadilan dalam penyelesaian sengketa ekonomi syariah dan menguatkan kewenangan absolut Pengadilan Agama dalam menyelesaikan sengketa ekonomi syariah melalui jalur Litigasi. Sedangkan kekosongan hukum yang ditimbulkan melalui non litigasi harus merujuk pada UU No 30 tahun 1999 tentang penyelesaian sengketa dilakukan melalui arbitrase atau alternatif penyelesaian sengketa yang meliputi konsultasi, negosiasi (perundingan), konsiliasi, mediasi non perbankan, pendapat atau penilaian ahli. Pengadilan Negeri dalam mengadili sengketa ekonomi syariah tidak dapat dipergunakan lagi dan tidak memiliki kekuatan hukum yang mengikat (non binding), dan hakim pengadilan negeri yang menerima sengketa ekonomi syariah wajib menolak karena sengketa ekonomi syariah bukan lagi menjadi kewenangannya.
\end{abstract}

Kata Kunci: Sengketa, Ekonomi Syariah, Pengadilan Agama.

\begin{abstract}
The aim of this research is to determine the resolution of sharia economic disputes through non-litigation channels and the legal strength of sharia financial institutions that still use the District Court as a litigation channels.The research is normative juridical, namely looking at the decision of the Constitutional Court No. 93 / PUU-X/2012 by analyzing the decision through a statute approach.Conclusions Since the decision of the Constitutional Court No. 93 / PUU-X / 2012, there will be no more dualism in the authority of the court in resolving sharia economic disputes and strengthening the absolute authority of the Religious Courts in resolving sharia economic disputes through Litigation channels. Whereas the legal vacuum created through non-litigation must refer to Law No. 30 of 1999 concerning dispute resolution carried out through arbitration or alternative dispute resolution which includes consultation, negotiation, conciliation, non-banking mediation, expert opinion or judgment.The District Court in adjudicating sharia economic disputes cannot be used again and does not have a binding legal force, and a district court judge who accepts sharia economic disputes must refuse because sharia economic disputes are no longer their authority.
\end{abstract}

Keywords: Disputes, sharia economic, Religious Courts.

\section{A. PENDAHULUAN}

Perbankan merupakan salah sektor yang mempunyai peranan penting di berbagai bidang, antara lain dalam kegiatan masyarakat khususnya di bidang financial, serta kegiatan ekonomi untuk memenuhi kebutuhan pribadi seseorang. Dewasa ini masyarakat seolah-olah tidak dapat dipisahkan dari dunia perbankan sebab sudah bukan menjadi rahasia umum lagi bahwa jasa perbankan sangat membantu kegiatan perekonomian.

Kebutuhan masyarakat muslim Indonesia adanya bank yang beroperasi sesuai dengan prinsip syariah secara yuridis baru mulai diatur dalam Undang-undang No 7 tahun 1992 tentang perbankan. Dalam Undangundang tersebut eksistensi perbankan syariah belum dinyatakan secara eksplisit, melainkan baru disebutkan dengan istilah "bank berdasarkan prinsip bagi hasil". 
Praktik bisnis syariah di Indonesia mulai berkembang dengan perkembangan keinginan dan harapan umat Islam yang menjadi sebagian besar penduduk Indonesia. Keinginan tersebut berkembang seiring dengan berkembangnya upaya pemahaman terhadap kegiatan-kegiatan ekonomi yang berdasarkan syari'ah Islam pada awal tahun 1990-an. Perkembangan ekonomi syari'ah di Indonesia dimulai dengan pembentukan perbankan syari'ah. Dalam perkembangan selanjutnya, praktik ekonomi syari'ah tidak hanya terbatas kepada praktik pendirian dan operasional perbankan saja, tetapi lebih meluas kepada kegiatan niaga lainnya, seperti pembiayaan dan lembaga keuangan non bank lainnya. Bidang-bidang usaha yang dikembangkan tersebut antara lain adalah Asuransi Syari'ah, Reksa Dana Syari'ah dan Obligasi Syari'ah, dan lain-lain.(Hasan, 2009).

Untuk mempertahankan perkembangan ekonomi syariah, dukungan hukum (legal support) dari berbagai aspek sangat diperlukan. Salah satu aspek penting adalah mengenai penyelesaian sengketa ekonomi syariah yang mungkin terjadi antara bank syariah, nasabah, dan pemangku kepentingan (stakeholders). Oleh karena itu perbankan syariah didasarkan pada prinsip syariah (syariah based), maka mekanisme penyelesaian sengketa juga harus berdasarkan syariah (in compliance with shariah).

Landasan utama beroperasinya bank syariah di Indonesia dalam Undang-undang No. 21 Tahun 2008 tentang Perbankan Syariah. Pasal 55 ayat (1) UU No. 21 Tahun 2008 disebutkan kewenangan menyelesaikan sengketa perbankan syariah adalah kewenangan Pengadilan Agama, kemudian ayat (2) membuka peluang untuk menyelesaikan sengketa di luar Pengadilan Agama sepanjang yang diperjanjikan dalam akad, yaitu melalui Musyawarah, Mediasi, Badan Arbitrase Syariah Nasional (Basyarnas) dan
Pengadilan Negeri. Selanjutnya dalam penjelasan Pasal 55 ayat (3) disebutkan, bahwa penyelesaian sengketa harus sesuai dengan prinsip syariah.

Putusan Mahkamah Konstitusi Nomor 93/PUU-X/2012 merupakan jawaban dari konflik antar norma hukum antara Undang-undang Nomor 3/2006 dengan Undang-undang Nomor 21/2008. Putusan tersebut untuk menguatkan posisi kewenangan Pengadilan Agama yang telah di sebutkan oleh Undang-undang Nomor 3/2006 dalam hal menyelesaikan sengketa ekonomi syariah. Dengan adanya putusan Mahkamah Konstitusi tersebut maka berakhir dualisme penyelesaian sengketa ekonomi syariah melalui jalur litigasi.

Namun, putusan MK Nomor 93/PUU$\mathrm{X} / 2012$ juga melahirkan persoalan baru setelah dihapuskan pasal 55 ayat 2 dimana terjadi kekosongan hukum yaitu tidak adanya aturan mengenai penyelesaian sengketa ekonomi syariah melalui jalur non-litigasi. Realita yang terjadi dalam ruang lingkup perbankan syariah meskipun kewenangan absolut penyelesaian sengketa ekonomi syariah telah menjadi kewenangan Pengadilan Agama tetapi masih ada perbankan syariah yang masih menggunakan Pengadilan Negeri, padahal dalam putusan MK tersebut sudah menghapus Pengadilan Negeri dalam hal menyelesaikan sengketa ekonomi syariah. Selanjutnya disini penulis ingin mengkaji lebih lanjut bagaimana penyelesaian sengketa ekonomi syariah melalui jalur non-litigasi dan bagaimana kekuatan hukum perbankan syariah yang menggunakan Pengadilan Umum.

Adapun penelitian ini bertujuan untuk mengetahui dan memberikan gambaran mengenai penyelesaian sengketa ekonomi syariah pasca putusan Mahkamah Konstitusi No. 93/PUU-X/2012 dan hukum yang ditimbulkan terhadap akad yang masih memuat klausula penyelesaian 
sengketa ekonomi syariah melalui Pengadilan Negeri.

\section{B. KAJIAN LITERATUR}

Setelah melakukan penelusuran terhadap beberapa literatur, ada beberapa penelitian yang memiliki korelasi tema yang membahas mengenai penyelesaian sengketa ekonomi syariah, misalnya yang telah dilakukan oleh beberapa peneliti. Ratna Sofianan (2015), mengkaji mengenai Kewenangan Badan Arbitrase Syariah Nasional terhadap penyelesaian sengketa ekonomi syariah sebelum dan sesudah putusan MK No 93/PUU-X/2012 dan implikasi tugas dan wewenang Badan Arbitrase Syariah Nasional dalam penyelesaian sengketa ekonomi syariah pasca putusan MK No 93/PUU-X/2012 tentang pengujian konstitusional UU No 21 Tahun 2008 pasal 55 ayat 2 tentang perbankan syariah. Hasil penelitian ini menunjukkan sebelum lahirnya UndangUndang Nomor 21 Tahun 2008 tentang perbankan syariah penyelesaian sengketa dilakukan dominan melalui Badan Arbitrase Syariah Nasional dan Pengadilan Negeri, setelah lahirnya Undang-Undang Nomor 21 Tahun 2008 penyelesaian sengketa ekonomi syariah di atur dalam pasal 55 yang menyatakan selain Pengadilan Agama juga dapat dilakukan sesuai isi akad melalui : Musyawarah, Mediasi perbankan, Basyarnas dan Peradilan Umum. Dan implikasi tugas dan kewenangan BASYARNAS masih mengambang karena belum adanya revisi Undang-undang untuk memperkuat tugas dan kewenangan Basyarnas dalam menyelesaikan sengketa ekonomi syariah.

Penelitian lainnya dilakukan oleh Farhan Wildani (2016), mengkaji Pilihan Forum Penyelesaian Sengketa Perbankan Syariah Pasca Putusan Mahkamah Konstitusi NO.93/PUU-X/2012 (Studi Kasus di PT. Bank Pembiayaan Rakyat Syariah Sarana Prima Mandiri Pamekasan Madura).
Penelitian ini mendeskripsikan dan menganalisis pilihan forum penyelesaian sengketa di BPRS SPM, kesimpulan dalam penelitian ini pertama bahwa BPRS SPM memilih Pengadilan Negeri sebagai penyelesaian sengketa, kedua politik hukum penyelesaian sengketa ekonomi syariah terjadi konflik norma dikarenakan ada peraturan perundang-undangan yang tumpang tindih.

Adapun perbedaan kedua penelitian tersebut dengan kajian ini terletak di fokus forum penyelesaian sengketa ekonomi syariah pasca putusan Mahkamah Konstitusi No. 93/PUU-X/2012 dimana dalam putusan tersebut telah dihapus pasal 55 ayat 2 Undang-undang nomer 21 tahun 2008 yang memuat choice of forum dalam penyelesaian sengketa ekonomi syariah melalui musyawarah, media perbankan, arbitrase syariah nasional Indonesia atau badan arbitrase lainnya dan Peradilan Umum tidak berlaku lagi. Kemudian putusan MK tersebut juga menimbulkan problematika hukum baru berupa kekosongan hukum yaitu tidak adanya aturan mengenai penyelesaian sengketa melalui choice of forum, karena pasal yang mengatur masalah non litigasi sudah di hapus.

Perbedaan selanjutnya peneliti mengkaji kekuatan hukum yang timbul dari putusan Pengadilan Negeri terhadap sengketa ekonomi syariah dimana masih ada beberapa lembaga keuangan yang masih memuat klausula penyelesaian sengketa ekonomi syariah melalui Pengadilan Negeri yang mana hal tersebut akan merugikan lembaga keuangan sendiri maupun nasabah. Dengan begitu, diharapkan dapat menghasilkan gambaran mengenai choice of forum penyelesaian sengketa ekonomi syariah dan kekuatan hukum dari putusan dari Pengadilan Negeri.

\section{a. Sengketa Ekonomi Syariah}


Pada dasarnya, kegiatan ekonomi adalah kegiatan yang berkaitan dengan masalah harta dan benda, dengan kata lain kegiatan ekonomi adalah kegiatan manusia untuk mencapai kemakmuran hidupnya. Kegiatan ekonomi bisa terjalin apabila terjadi transaksi antara satu pelaku ekonomi dengan pelaku ekonomi lainnya. Namun dalam pelaksanaan transaksi tersebut terkadang menimbulkan sengketa dikemudian hari.

Secara etimologi, menurut KBBI, sengketa adalah sesuatu yang menyebabkan perbedaan pendapat, pertengkaran, perbantahan, atau perselisihan. ${ }^{\text {i Adapun }}$ secara istilah, sengketa adalah pertentangan antara dua pihak atau lebih yang berawal dari persepsi yang berbeda tentang suatu kepentingan atau hak milik yang dapat menimbulkan akibat hukum bagi keduanya dan dapat diberikan sanksi hukum terhadap salah satu diantara keduanya.

Menurut Siti Megadianty Adam dan Takdir Rahmadi, sebagaimana dikutip Rachmadi Usman, dalam kosakata Inggris terdapat 2 (dua) istilah, yakni "conflict"dan "dispute", yang kedua-duanya mengandung pengertian tentang adanya perbedaan di antara kedua pihak atau lebih, tetapi keduanya dapat dibedakan. Kosa kata conflict sudah diserap ke dalam bahasa Indonesia menjadi "konflik", sedangkan kosa kata dispute dapat diterjemahkan dengan kosa kata "sengketa". Sebuah konflik, yakni sebuah situasi dimana 2 (dua) pihak atau lebih dihadapkan pada perbedaan kepentingan, tidak akan berkembang menjadi sengketa apabila pihak yang merasa dirugikan hanya memendam perasaan tidak puas atau keprihatinannya. Sebuah konflik berubah atau berkembang menjadi sebuah sengketa bilamana pihak yang merasa dirugikan telah menyatakan rasa tidak puas atau keprihatinannya, baik secara langsung kepada pihak yang dianggap sebagai penyebab kerugian atau pihak lain.

Selanjutnya, ekonomi syariah (Islamic Economics) diartikan sebagai ilmu yang mempelajari tata kehidupan masyarakat dalam memenuhi kebutuhan hidupnya untuk mencapai ridha Allah,(Sarkaniputra, 2005) dengan kata lain merupakan perbuatan atau kegiatan usaha yang dilaksanakan menurut prinsip syariah, atau juga dapat diartikan sebagai suatu sistem ekonomi yang didasarkan pada ajaran dan nilai-nilai Islam.

Berdasarkan pengertian di atas, maka dapat ditarik kesimpulan bahwa yang dimaksud dengan sengketa ekonomi syariah adalah suatu pertentangan antara dua pihak atau lebih pelaku ekonomi yang kegiatan usahanya yang dilaksanakan menurut prinsip-prinsip dan asas hukum ekonomi syariah yang disebabkan persepsi yang berbeda tentang suatu kepentingan atau hak milik yang dapat menimbulkan akibat hukum bagi keduanya dan dapat diberikan sanksi hukum terhadap salah satu diantara keduanya.

Secara garis besar, sengketa ekonomi syariah dapat diklasifikasikan menjadi 3 (tiga), yaitu:

a. Sengketa di bidang ekonomi syariah antara lembaga keuangan dan lembaga pembiayaan syariah dengan nasabahnya;

b. Sengketa di bidang ekonomi syariah antara lembaga keuangan dan lembaga pembiayaan syariah;

c. Sengketa di bidang ekonomi syariah antara orang-orang yang beragama Islam, yang mana akad perjanjiannya disebutkan dengan tegas bahwa kegiatan usaha yang dilakukan adalah berdasarkan prinsip-prinsip syariah. 
b. Sumber Hukum Dalam

Menyelesaikan Sengketa Ekonomi Syariah.

Sumber hukum adalah segala apa saja yang menimbulkan aturan-aturan yang mempunyai kekuatan yang bersifat memaksa, yakni aturan-aturan yang kalau dilanggar mengakibatkan sanksi yang tegas dan nyata.(Kansil, 1986) Sumber hukum segala sesuatu yang melahirkan hukum. Sumber hukum dapat pula disebut sebagai asal muasal hukum.

Adapun sumber hukum ekonomi syariah adalah sumber hukum formil dan sumber hukum materil. Berikut ini, sumber hukum yang dapat digunakan sebagai dasar hukum untuk menyelesaikan sengketa ekonomi syariah:(Manan, 2005)

\section{Hukum Formil}

Sumber hukum formil adalah pembicaraan ilmu hukum, bukan pembicaraan filsafat hukum. Sumber hukum formil atau bentuk-bentuk dimana kita dapat menemukan atau mengenal hukum yang berlaku sebagai hukum positif di suatu Negara.(Usman, 2001) Sumber hukum formil memiliki bentuk yang berlaku secara umum dan telah diketahui atau berlaku umum.

Hukum Acara yang berlaku di Pengadilan Agama untuk mengadili sengketa ekonomi syari'ah adalah hukum acara yang berlaku dan dipergunakan pada lingkungan Peradilan Umum/Negeri. Ketentuan ini sesuai dengan ketentuan Pasal 54 Undang-Undang Nomor 7 Tahun 1989 Jo. Undang-Undang Nomor 3 Tahun 2006.

\section{Sumber Hukum Materiil}

Sumber hukum materiil adalah sumber darimana hukum berasal atau sumber tempat materi hukum diambil. Sumber hukum materiil merupakan sumber yang dilihat dari segi isinya dan sumber hukum inilah yang menjadi faktor yang membantu pembentukan hukum.(Dewi, 2012) Biasanya yang menjadi sumber-sumber hukum materil adalah aneka gejala yang ada dalam kehidupan masyarakat, baik yang telah menjelma menjadi peristiwa maupun yang belum menjelma menjadi peristiwa. Pembicaraan sumber hukum materiil merupakan salah satu bidang kajian filsafat hukum.

Sumber-sumber hukum yang sah dan diakui secara umum, khususnya di bidang bisnis adalah isi perjanjian, undang-undang, yudisprudensi, kebiasaan, perjanjian internasional, dan ilmu pengetahuan.(Amal, 1990)

Adapun bagi lingkungan Pengadilan Agama, sumber-sumber hukum yang terpenting untuk dijadikan dasar dalam mengadili perkara ekonomi syariah setelah Al-quran dan As-Sunnah sebagai sumber utama, antara lain adalah:

a. Undang-undang

b. Fatwa Dewan Syari'ah Nasional (DSN)

c. Aqad Perjanjian (Kontrak)

d. Fiqih dan Ushul Fiqih

e. Adat Kebiasaan

f. KHES (Kompilasi Hukum Ekonomi Syariah)

g. Yurisprudensi dan Doktrin Ekonomi Syariah

\section{Penyelesaian Sengketa Ekonomi Syariah Menurut UU No 21 Tahun 2008.}

Penyelesaian sengketa ekonomi syariah bisa dilakukan dengan dua cara;

a. Penyelesaian sengketa melalui litigasi. 
Litigasi merupakan proses gugatan atas suatu konflik yang diritualisasikan untuk menggantikan konflik sesungguhnya, dimana para pihak memberikan kepada seorang pengambil keputusan dua pilihan yang bertentangan. Lembaga litigasi merupakan sistem penyelesaian sengketa melalui peradilan. Penyelesaian sengketa melalui litigasi ini diatur dalam UU 48/2009 tentang Kekuasaan Kehakiman.(Hudiata, 2012)

Menurut ketentuan pasal 10 ayat (1) undang-undang Nomor 14 tahun 1970 jo undang-undang nomor 35 tahun 1999 jo undang-undang nomor 4 tahun 2004 jo undang-undang nomor 48 tahun 2009 tentang Kekuasaan Kehakiman secara eksplisit menyebutkan bahwa di Indonesia ada 4 Lingkungan lembaga peradilan yaitu Peradilan Umum, Peradilan Agama, Peradilan Militer dan Peradilan Tata Usaha Negara (TUN).(Nurul, 2012)

Secara umum, kekuasaan (competency) peradilan dapat dibedakan menjadi dua, yakni kekuasaan relatif (relative competency) dan kekuasaan absolut (absolute competency). Kekuasaan relatif berkaitan dengan wilayah, sementara kekuasaan absolut berkaitan dengan orang (kewarganegaraan dan keagamaan seseorang) dan jenis perkara. Setelah pemberlakuan UndangUndang Nomor 3 tahun 2006 tentang Perubahan Atas Undang-Undang Nomor 7 Tahun 1989 tentang Peradilan Agama, perluasan kompetensi absolut peradilan agama dilakukan. Dari segi susunan undang-undang, ketentuan mengenai kekuasaan absolut peradilan agama dijelaskan dalam dua tempat: (1) ketentuan yang bersifat umum yang ditetapkan pada bagian dua tentang kedudukan peradilan agama; dan (2) ketentuan rincian yang ditetapkan pada bagian kekuasaan pengadilan. Dalam ketentuan mengenai kekuasaan absolut peradilan agama yang bersifat umum ditetapkan bahwa peradilan agama adalah salah satu pelaksana kekuasaan kehakiman bagi pencari keadilan yang beragama Islam mengenai perkara perdata tertentu.(Anshori, 2007) Pengadilan Agama sebagai salah satu badan peradilan yang melaksanakan kekuasaan kehakiman untuk menegakkan hukum dan keadilan bagi orang-orang yang beragama Islam, yang sebelumnya berdasarkan Undang-Undang Nomor 7 Tahun 1989, hanya berwenang menyelesaikan perkara perkawinan, waris, wasiat, hibah, wakaf, zakat, infaq, shodaqah, kemudian berdasarkan Pasal 49 huruf i UndangUndang Nomor 3 Tahun 2006, kewenangan absolut pengadilan agama diperluas, termasuk kewenangan untuk menyelesaikan sengketa di bidang Ekonomi Syariah.

Adapun kewenangan absolut mengenai Peradilan yang berhak menyelesaikan sengketa ekonomi syariah menurut isi pasal 49 huruf (i) UU 3/2006 yaitu :

"Pengadilan Agama bertugas dan berwenang memeriksa, memutus, dan menyelesaikan perkara di tingkat pertama antara orang-orang yang beragama Islam di bidang: Perkawinan, waris, wasiat, hibah, wakaf, zakat, infaq, shadaqah dan Ekonomi syariah".

Selanjutnya yang dimaksud dengan istilah ekonomi syariah adalah perbuatan atau kegiatan usaha yang dilaksanakan menurut prinsip syariah yang meliputi bank syariah, lembaga keuangan mikro syariah, asuransi syariah, reasuransi syariah, reksadana syariah, obligasi syariah dan surat berharga berjangka menengah syariah, sekuritas syariah, pembiayaan syariah, pegadaian syariah, dana pensiun lembaga keuangan syariah dan bisnis syariah.(Sismarwoto, 2009)

Dari penjelasan di atas dapat dipahami bahwa Pengadilan Agama berwenang menyelesaikan sengketa perbankan syariah yang kemudian, kewenangan Pengadilan Agama diperkuat kembali dalam Pasal 55 
(1) UU No. 21 Tahun 2008 tentang Perbankan Syariah yang menyatakan bahwa penyelesaian sengketa perbankan syariah dilakukan oleh Pengadilan dalam lingkungan Peradilan Agama.

\section{b. Penyelesaian sengketa melalui non-litigasi.}

Penyelesaian sengketa melalui jalur non-litigasi ini umumnya dinamakan dengan Alternative Dispute Resolution (ADR), yaitu mekanisme penyelesaian sengketa alternatif di luar pengadilan. Adapun proses penyelesaian secara non litigasi dapat dilakukan melalui beberapa institusi seperti yang dijelaskan dalam pasal 55 ayat 2 UU No. 21 Tahun 2008 tentang Perbankan Syariah:

1. Musyawarah mufakat,

2. Mediasi BI (untuk penyelesaian sengketa antar bank), mediasi pada Dewan Pengawas Syariah (DPS) masing-masing bank syariah dalam hal penyelesaian sengketa antar bank syariah dengan nasabahnya,

3. Badan Arbitrase Syariah Nasional (BASYARNAS).

4. Melalui Peradilan Umum.(Basir, 2009)

Ini merupakan langkah yang tepat dan layak untuk diapresasi karena ada asas kebebasan berkontrak memilih jalur yang ingin ditempuh ketika terjadi sengketa. Akan tetapi, masalah muncul ketika Pengadilan Negeri juga diberikan kewenangan yang sama dalam menyelesaikan sengketa ekonomi syariah. Terjadi dualisme penyelesaian sengketa dan ketidakpastian hukum serta tumpang tindih kewenangan dalam menyelesaikan suatu perkara yang sama oleh dua lembaga peradilan yang berbeda. Padahal, kewenangan ini jelas merupakan kewenangan absolut Pengadilan Agama sebagaimana diatur dalam Pasal 49 (i) UU No. 3 Tahun 2006 tentang Peradilan Agama.
Menurut Muladi, Penyelesaian sengketa melalui Alternative Dispute Resolution (ADR) mempunyai beberapa keunggulan dibandingkan dengan penyelesaian melalui badan litigasi atau pengadilan. Di antara keunggulan penyelesaian sengketa melalui Non-litigasi adalah:

1. Penyelesaian sengketanya dapat dilakukan dengan cara cepat;

2. Penyelesaian sengketa dapat dilaksanakan dengan biaya murah;

3. Tidak terikat dengan aturan hukum tertentu;

4. Bersifat Confidential;

5. Atas dasar prinsip win win solution;

6. Lebih parsitipatif;

7. Dapat mengurangi penumpukan perkara di Pengadilan tanpa mengurangi sifat profesionalisme. (Firdaus, 2001)

\section{METODE PENELITIAN}

Dalam penelitian hukum dengan subjek peraturan perundang-undangan dan putusan pengadilan dapat dikategorikan sebagai penelitian hukum doktrinal, yaitu penelitian inventarisasi hukum positif, asas-asas, penemuan hukum in concreto, sistem hukum dan sinkronisasi hukum.(Soemitro, 1990)

Metode pendekatan pada penelitian ini yang digunakan adalah metode penelitian yuridis normatif. Dalam metode penelitian yuridis normatif tersebut akan menelaah secara mendalam terhadap asas-asas hukum, peraturan perundang-undangan, yurisprudensi, dan pendapat ahli hukum serta memandang hukum secara komprehensif. Artinya hukum bukan saja sebagai seperangkat kaidah yang bersifat normatif atau apa yang menjadi teks undang-undang (law in book) tetapi juga melihat bagaimana bekerjanya hukum (law in action).

Data yang digunakan dalam penelitian ini 
adalah data sekunder yang disebut bahan hukum. Yaitu berupa inventarisasi berkas putusan Mahkamah Konstitusi No. 93/PUU-X/2012, peraturan perundangundangan, buku-buku, literatur, jurnal dan dokumen yang berkaitan dengan pokok masalah.

Penelitian normatif ini tentu harus menggunakan pendekatan perundangundangan, karena yang akan diteliti adalah berbagai aturan hukum yang menjadi fokus sekaligus tema sentral suatu penelitian di antaranya Undang-undang Nomor 50 tahun 2009 tentang kewenangan pengadilan agama, pasal 55 Undang-undang Nomor 21 tahun 2008 tentang perbankan syariah, putusan MK Nomor 93/PUU-X/2012 dan undang-undang yang berkenaan dengan sengketa ekonomi syariah.

\section{HASIL DAN PEMBAHASAN}

1. Penyelesaian Sengketa Ekonomi Syariah Pasca Putusan Mahkamah Konstitusi Nomor 93/PUU-X/2012

Dualisme kewenangan penyelesaian sengketa ekonomi syariah menjadi polemik dalam jagat hukum Indonesia. Hal tersebut menjadi problematika hukum yan $g$ menjadi perhatian para pihak. Problematika mengenai dualisme kewenangan ini semakin nyata dengan lahirnya Undangundang Republik Indonesia Nomor 21 Tahun 2008 Tentang Perbankan Syariah atau biasa dikenal dengan istilah UUPS. Pasal 55 ayat (1) UUPS menyebutkan bahwa "Penyelesaian sengketa Perbankan Syariah dilakukan oleh pengadilan dalam lingkungan Peradilan Agama”. Sementara pada Ayat (2) berbunyi: "Dalam hal para pihak telah memperjanjikan penyelesaian sengketa selain sebagaimana dimaksud pada ayat (1), penyelesaian sengketa dilakukan sesuai dengan isi Akad".
Penjelasan Pasal 55 Ayat (2) mempertegas, bahwa: Yang dimaksud dengan "penyelesaian sengketa dilakukan sesuai dengan isi Akad" adalah upaya sebagai berikut: a. musyawarah; b. mediasi perbankan; c. melalui Badan Arbitrase Syariah Nasional (Basyarnas) dan d. melalui pengadilan dalam lingkungan Peradilan Umum". Hal tersebut di atas tentunya tidak sesuai dengan Pasal 49 Undang-undang Republik Indonesia Nomor 3 Tahun 2006 tentang Peradilan Agama, yang dengan jelas dan tegas menyebutkan bahwa: "Pengadilan agama bertugas dan berwenang memeriksa, memutus, dan menyelesaikan perkara di tingkat pertama antara orang-orang yang beragama Islam di bidang: (i) ekonomi syariah" Penjelasan pasal 49 menegaskan bahwa salah satu kegiatan usaha ekonomi syariah adalah perbankan syariah.

Bunyi pasal-pasal tersebut bisa dimaknai bahwa terjadi inkonsistensi norma, yang memberikan opsional choice of litigation dalam penyelesaian sengketa perbankan syariah, yaitu antara Pengadilan agama dan Pengadilan Umum. Artinya, terdapat dualisme kewenangan penyelesaian sengketa perbankan syariah, yaitu di Pengadilan Umum dan Pengadilan Agama. Inkonsistensi norma tersebut menimbulkan ketidakpastian hukum bagi pencari keadilan dan bahkan mereduksi daya kompetensi peradilan agama. Inilah sebenarnya yang menjadi problematika hukum dalam konteks ini.

Dengan demikian, ketentuan pasal 55 ayat (2) UU 21/2008 secara yuridis bertentangan dengan UU 3/2006 yang lebih dahulu diterbitkan. Oleh karena itu, muncul pertanyaan kenapa undang-undang yang datang kemudian bisa bertentangan dengan undang-undang yang sebelumnya sudah mengatur tentang forum penyelesaian sengketa.

Adanya ketidakpastian hukum seperti inilah sehingga Dadang Achmad, Direktur CV Benua Engineering Consultant 
mengajukan judicial review ke Mahkamah Konstitusi, memohon pembatalan Pasal 55 ayat 2 dan ayat 3 UU No. 21 Tahun 2008 tentang Perbankan syariah dengan alasan bertentangan dengan Pasal 28 UUD 1945. Pada tanggal 29 Agustus 2013, Majelis Mahkamah Konstitusi membuat putusan atas perkara Nomor 93/PUU-X/2012, mengabulkan sebagian permohonan Dadang Achmad, menyatakan bahwa penjelasan Pasal 55 ayat 2 UU 21 Tahun 2008 tentang Perbankan Syariah bertentangan dengan UUD 1945 dan tidak mempunyai kekuatan hukum mengikat.

Perkara ini secara umum terkait dengan Pasal 55 ayat (2) dan (3) UndangUndang No. 21 tentang Perbankan Syariah yang mengatur tentang penyelesaian sengketa ekonomi syariah. Melalui putusan Mahkamah Konstitusi tersebut dapat memberikan jawaban dari konflik antar norma hukum (antinomi hukum) antara UU 3/2006 dengan UU 21/2008. Putusan tersebut pada dasarnya menguatkan kewenangan Pengadilan Agama yang telah diamanatkan oleh UU 3/2006 dalam menyelesaikan sengketa ekonomi syariah dengan menyatakan tidak ada lagi dualisme penyelesaian sengketa ekonomi syariah melalui jalur litigasi yaitu Pengadilan Agama dan Pengadilan Negeri.

Adapun amar putusan majelis hakim Mahkamah Konstitusi dengan Nomor perkara 93/PUU-X/2012 sebagai berikut:

1. Mengabulkan permohonan Pemohon untuk sebagian;

a) Penjelasan Pasal 55 ayat (2) UndangUndang Nomor 21 Tahun 2008 tentang Perbankan Syariah (Lembaran Negara Republik Indonesia Tahun 2008 Nomor 94, Tambahan Lembaran Negara Republik Indonesia Nomor 4867) bertentangan dengan Undang-Undang Dasar Negara Republik Indonesia Tahun1945;

b) Penjelasan Pasal 55 ayat (2) UndangUndang Nomor 21 Tahun 2008 tentang
Perbankan Syariah (Lembaran Negara Republik Indonesia Tahun 2008 Nomor 94, Tambahan Lembaran Negara Republik Indonesia Nomor 4867) tidak mempunyai kekuatan hukum mengikat.

2. Memerintahkan pemuatan putusan ini dalam berita Negara Republik Indonesia sebagaimana mestinya.

3. Menolak permohonan pemohon untuk selain dan selebihnya.

Di satu sisi Mahkamah Konstitusi telah memberikan kepastian hukum mengenai penyelesaian sengketa melalui jalur litigasi dengan menetapkan kewenangan absolut Pengadilan Agama, namun di segi lain putusan tersebut juga menimbulkan problematika hukum baru yaitu tidak adanya kepastian hukum bagi pihak yang ingin menyelesaikan sengketa ekonomi syariah melalui jalur non-litigasi dikarenakan putusan mahkamah konstitusi telah menghapus pasal 55 ayat 2 UU No 21 Tahun 2008 yang memuat bentuk-bentuk penyelesaian sengketa ekonomi syariah melalui jalur non-litigasi, keadaan ini menjadikan pasal 55 ayat 2 menjadi kabur sehingga mengakibatkan kekosongan hukum tentang penyelesaian sengketa ekonomi syariah melalui jalur nonlitigasi.

Untuk menjawab problematika hukum tersebut penulis telah mewancarai Wakil Ketua Pengadilan Agama Kota Cilegon Provinsi Banten Drs. Hendi Rustandi SH, menyatakan bahwa Pengadilan tidak boleh menolak memeriksa, mengadili dan memutuskan suatu perkara yang diajukan kepadanya dengan alasan hukumnya tidak ada atau tidak jelas, oleh karena itu maka hakim wajib mencari hukumnya. Adapun metode yang tepat untuk menjawab problematika hukum tersebut dengan cara menginterpretasi sistematis atau logis yang menafsirkan peraturan dengan menghubungkan peraturan atau Undangundang yang lain. Maka dalam hal ini, pasal 55 ayat 2 UU No. 21 Tahun 2008 dapat 
dikaitkan dengan penafsiran sistematis melihat UU No. 30 Tahun 1999 tentang penyelesaian sengketa dapat dilakukan melalui arbitrase atau alternatif penyelesaian sengketa yang meliputi konsultasi, negosiasi (perundingan), konsiliasi, mediasi non perbankan dan pendapat atau penilaian ahli.

Adapun putusan Pengadilan Negeri terhadap sengketa ekonomi syariah tidak bersifat mengikat lagi dikarenakan setelah putusan Mahkamah Konstitusi No. 93/PUU-X/2012 menyatakan pasal 55 ayat 2 tidak mempunyai kekuatan hukum sehingga dapat bisa diambil kesimpulan bahwa penyelesaian sengketa ekonomi syariah melalui jalur litigasi menjadi kewenangan absolut Pengadilan Agama.

\section{KESIMPULAN}

Berdasarkan hasil kajian dan analisis penulis terhadap hasil penelitian yang telah diuraikan sebelumnya, maka dapat diambil kesimpulan sebagai berikut:

Sejak adanya putusan Mahkamah Konstitusi No. 93/PUU-X/2012 yang ditetapkan pada hari Kamis tanggal 29 Agustus 2013, maka tidak ada lagi dualisme kewenangan pengadilan dalam menyelesaikan sengketa ekonomi syariah. Putusan tersebut menguatkan kewenangan absolut Pengadilan Agama dalam hal menyelesaikan sengketa ekonomi syariah melalui jalur Litigasi. Sedangkan kekosongan hukum yang ditimbulkan akibat dihapuskan pasal 55 ayat 2 (dua) melalui non litigasi harus merujuk pada UU No 30 tahun 1999 tentang penyelesaian sengketa dapat dilakukan melalui arbitrase atau alternatif penyelesaian sengketa yang meliputi konsultasi, negosiasi (perundingan), konsiliasi, mediasi non perbankan, pendapat atau penilaian ahli.

Pengadilan Negeri dalam mengadili sengketa ekonomi syariah tidak dapat dipergunakan lagi dan tidak memiliki kekuatan hukum yang mengikat (non binding), dan hakim pengadilan negeri yang menerima sengketa ekonomi syariah wajib menolak karena sengketa ekonomi syariah bukan lagi menjadi kewenangannya atau dengan kata lain bukan kewenangan absolut Pengadilan Negeri.

\section{DAFTAR PUSTAKA}

Amal, T. A. (1990). Islam dan Tantangan Modernitas Studi atas Pemikiran Hukum Fazlur Rahman. Bandung: Mizan.

Anshori, A. G. (2007). Peradilan Agama di Indonesia Pasca UU No. 3 Tahun 2006 (Sejarah, Kedudukan, dan Kewenangan). Yogyakarta: UII Press.

Basir, C. (2009). Penyelesaian Sengketa Perbankan Syariah di Pengadilan Agama dan Mahkamah Syariah. Jakarta: Kencana.

Dewi, L. R. (2012). Memahami Hukum Dalam Pengantar Ilmu Hukum. Serang: Dinas Pendidikan Provinsi Banten.

Firdaus, D. (2001). Prospek Law Enforcement Arbitrase DI Indonesia, Dalam Prospek Pelaksanaan Arbitrase Di Indonesia. Bandung: Citra Aditya Bakti.

Hasan, Z. (2009). Undang-Undang Perbankan Syariah Titik Temu Hukum Islam dan Hukum Nasional. Jakarta: Rajawali Pers.

Hudiata, E. (2012). Penyelesaian Sengketa Perbankan Syariah : Pasca Putusan MK Nomor 93/PUU-X/2012 : Litigasi Dan Nonlitigasi. Yogyakarta: UII Press.

Kansil, C. S. T. (1986). Pengantar Ilmu Hukum dan Tata Hukum Indonesia. Jakarta: Balai Pustaka. 
Manan, A. (2005). Penerapan Hukum Acara Perdata di Lingkungan Peradilan Agama. Jakarta: Prenada Media.

Nurul, D. (2012). Penyelesaian Sengketa Dalam Praktik Perbankan Syariah. Yogyakarta: Nuha Medika.

Sarkaniputra. (2005). Adil dan Ihsan dalam Perspektif Ekonomi Islam. Jakarta: P3EI UIN Syarif Hidayatullah.

Sismarwoto, E. (2009). Prinsip-Prinsip Ekonomi Syari'ah. Semarang: Pustaka Magister.

Soemitro, R. (1990). Metodologi Penelitian Hukum dan Jurimetri. Jakart: Ghalia Indonesia.

Usman, S. (2001). Hukum Islam : Asas-asas dan Pengantar Studi Hukum Islam dalam Tata Hukum Indonesia. Jakarta: Gaya Media Pratama. 